\title{
A new harvestman species (Arachnida: Opiliones: Phalangiidae: Homolophus) from Nakhichevan Autonomous Republic (Azerbaijan)
}

\author{
Nataly Yu. SNEGOVAYA \\ Zoological Institute NAS of Azerbaijan, passage 1128, block 504, Baku AZ 1073 Azerbaijan. \\ e-mail: snegovaya@yahoo.com
}

\begin{abstract}
A new harvestman species Homolophus nakhichevanicus sp.n of the family Phalangiidae with photos and drawings is described from mountains in territory of Nakhichevan Autonomous Republic, Azerbaijan. This is eighth harvestmen species from this territory.
\end{abstract}

Key words: Harvestmen, Homolophus, new species, Nakhichevan

\section{INTRODUCTION}

Nakhichevan Autonomous Republic (Naxçıvan Muxtar Respublikası) is situated in the South-East of the Transcaucasus plateau (Fig. 1). The average height above sea level is 1,450 m. The majority of the territory of Nakhichevan Autonomous Republic is surrounded by the Zangazur and Daralayaz mountain ridges of the Minor Caucasus. The Nakhichevan Autonomous Republic exclave of Azerbaijan, in the north and the east $(246 \mathrm{~km})$ borders to Armenia, in the west and south with Turkey $(11 \mathrm{~km})$ and Iran $(204 \mathrm{~km})$.

Before our (others listed in acknowledgements) explorations only seven harvestman species were known for Nakhichevan fauna (Morin 1937): Opilio parietinus (De Geer, 1778), $O$. coxipunctus (Søerensen, 1912), Phalangium saxatile C. Koch, 1839 var. znoiko Morin, 1937, Paropilio strandi Nosek, 1905, Eudasylobus nigricoxis Simon, 1878 var. znoiko Morin, 1937, Opilio lederi Roewer, 1911, Platybunus nigrovittatus Simon, 1879. However, some of these statements seems doubtful today and the revision of Morin's material would be needed. Unfortunately, it is not possible, because this collection was lost during the Second World War (report from Odessa State University).

As a result of new exploration of the territory of Nakhichevan, a new species has been found, belonging to the genus Homolophus Banks, which differs considerably from all known congeners.

Abbreviation used: ZMUM - Zoological Museum, University of Moscow, Russia; RCNS Reference collection of N.Snegovaya, Baku, Azerbaijan.

\section{TAXONOMY}

\section{Homolophus Banks, 1893}

The genus Homolophus Banks, 1893, currently includes approximately 20 species (Šilhavý, 1967, 1972; Cokendolpher 1987; Tsurusaki, Tchemeris \& Logunov, 2000; Tchemeris 2000; Tchemeris, Logunov \& Tsurusaki 1998; Staręga 2003; Snegovaya \& Staręga, 2008) from various part of Eurasia (Central Asia, Japan, Siberia, China, etc.). Revision of this genus is needed, because there are some doubtful species (long legged group of species, such as Homolophus potanini (Simon, 1895) and some others). Considering the changing diagnosis of 
the genus by different authors (Cokendolpher 1987, Tsurusaki, Tchemeris \& Logunov 2000, Snegovaya \& Starega, 2008), I conclude that the basic difference between Opilio and Homolophus is in the structure of the penis. According to the generic diagnosis provided by Snegovaya and Starega (2008), the "Penis without lateral incisions or similar structures in the apical part of the shaft; shaft often flattened dorso-ventrally, particularly in distal part; glans cuneiform, in profile mostly triangular with rounded "lower" corner; stylus relatively long".

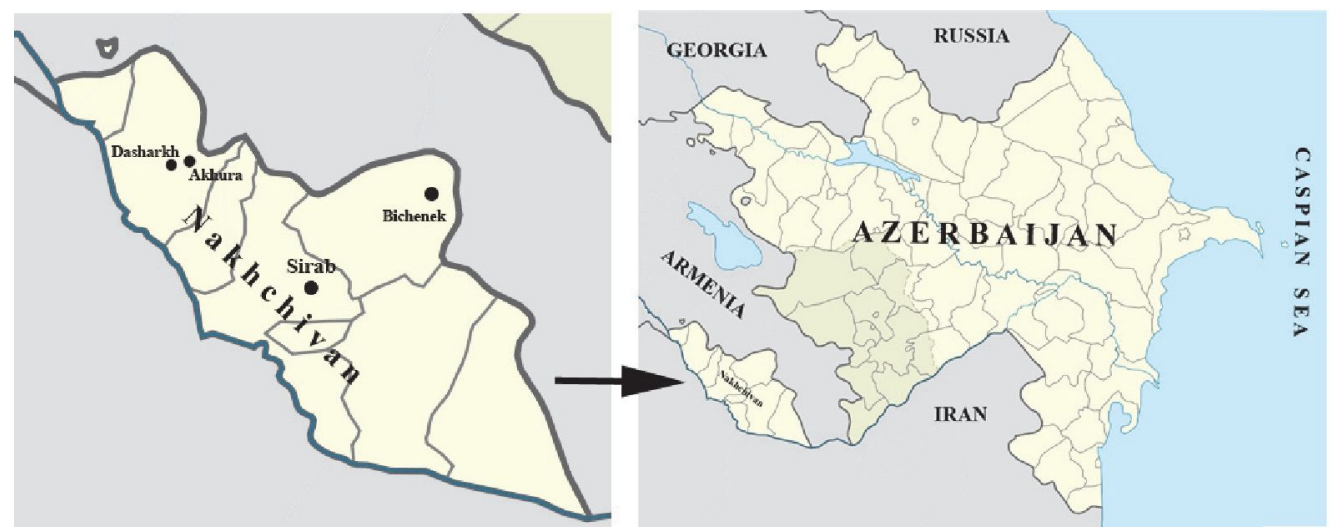

Fig. 1. Type locality of Homolophus nakhichevanicus sp. n. and the location of its known stands.
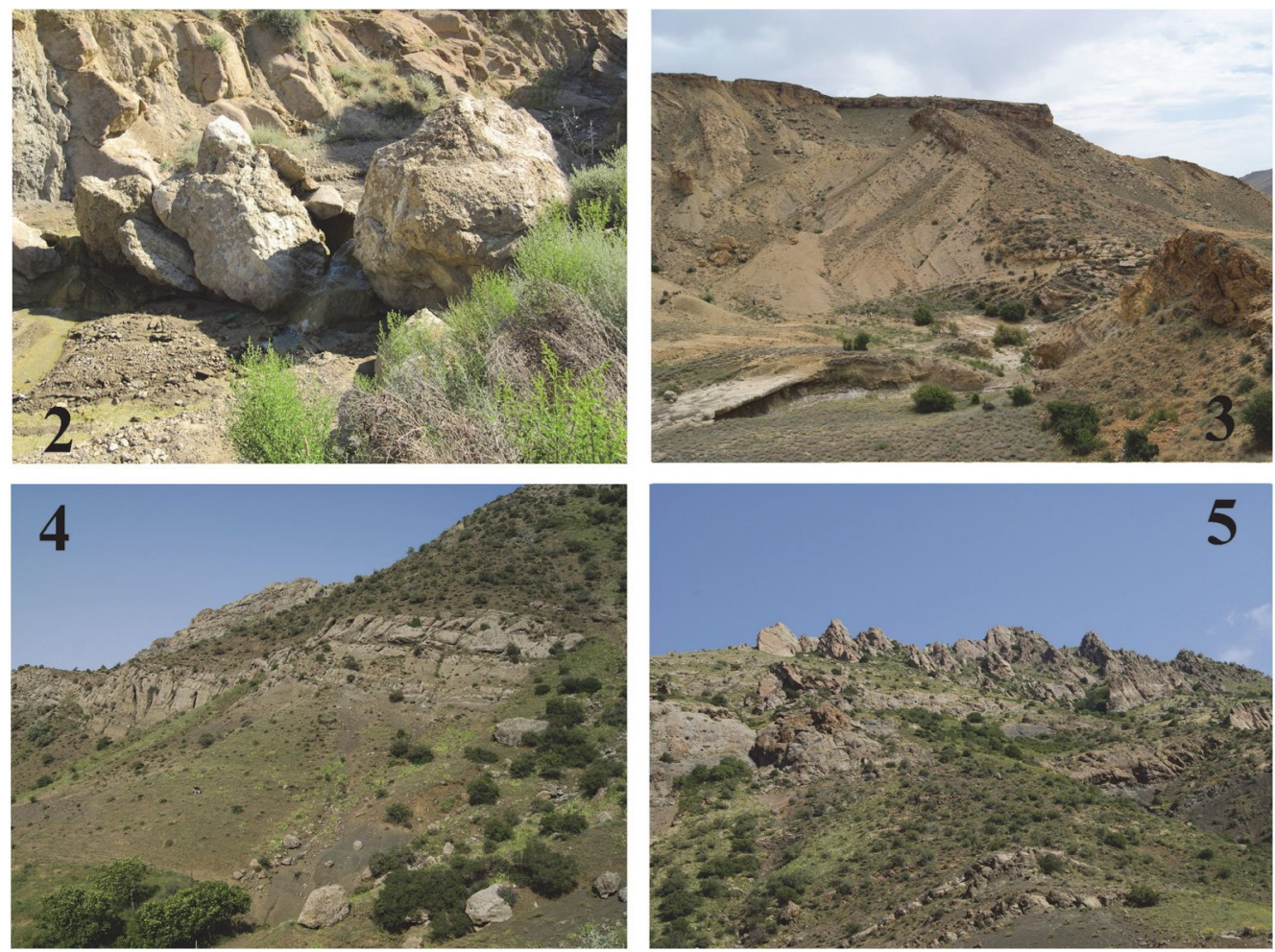

Figs 2-5. Habitat of Homolophus nakhichevanicus sp. n.; 2-3 - type locality from Babek distr., Sirab Village; 4-5 Shakhbuz distr., environs of Bichenek Village. 
The genus Homolophus was incorrectly marked for the first time from the territory of Azerbaijan (Homolophus azerbaijanicus, Lenkoran, South Azerbaijan) by Snegovaya \& Starega (2011). Despite this, the taxonomic status of that species needs further study. Species placed in Homolophus were earlier noted also from Turkey - Homolophus turcicus (Roewer, 1959) and $H$. funestus L. Koch, 1877 (Roewer 1959; Kurt et al. 2008), but the second (H. funestus) recognision (Kurt et al.) was probably misidentified.

\section{Homolophus nakhichevanicus sp. $\mathbf{n}$.}

(Figs 6-20)

Material. Holotype: 1 \& (ZMUM), Nakhichevan, Babek distr., Sirab, $1192 \mathrm{~m}$, $39^{\circ} 18.828^{\prime}$ N, $45^{\circ} 31.412^{\prime} E$, 21 June 2011 , leg. N. Snegovaya. Paratypes: 1 (RCNS), Sharur distr., ca $3 \mathrm{~km}$ E of Akhura Vill., 39 $34^{\prime} \mathrm{N}, 4^{\circ} 11^{\prime} \mathrm{E}, 1400 \mathrm{~m}, 2$ June 2003, leg. H. Aliyev; 2 우, 1 juv. (RCNS) Sharur distr., Dasharkh Vill., 39'33.629'N, 4502.53'E, 870 m, 1-4 June 2003, leg. Yu. Marusik; 12 juv. (RCNS), in the same locality, May-June 2003, leg. H. Aliyev; 2 ¿े, 1 juv. (RCNS), Shakhbuz distr., environs of Bichenek Vill., 1668 m, 24 June 2012, $39^{\circ} 31.301^{\prime}$ N, $45^{\circ} 46.197^{\prime}$ E, leg. H. Aliyev (Fig. 1).

Etymology. The species is named after the type locality, Nakhichevan AR (Azerbaijan).

Habitat. This species was collected under stones on sandy slopes (Figs 2-5).

Male. Body $5.7 \mathrm{~mm}$ long, 3.2 wide. Body nearly rectangular, covered by large, blacktipped denticles (Figs 6-7). Eye mound low, twice its diameter from the anterior margin of the carapace, without denticles and setae. Anterior margin of cephalothorax with group of large denticles, forming a crown. Venter covered only with setae. Body yellow with dark and light spots of different sizes and shapes. Dorsum with longitudinal row of whitish-yellow dots forming a stripe.

Legs not very long, pair I slightly thickened. All leg segments with longitudinal rows of large denticles, especially femora. Lengths of legs: I $3.5+1.4+3.0+4.4+5.4=17.7$, II $6.6+2.0+7.0+6.6+11.5=33.7$, III $3.6+1.5+3.4+4.6+5.4=18.5$, IV 5.0+1.6+4.5+6.5+7.5 = 25.1.

Chelicera not enlarged, I and II segment dorsally with denticles (Figs 8-9). I segment 2.0, II -2.25 . Pedipalps robust, femur and tibia dorsally and ventrally covered with denticles, patella dorsally with denticles (Figs 10-11). Length of palpal segments: femur 1.5, patella 0.7, tibia 1.1, tarsus 1.75; total length 1.41.

Penis base not very wide, corpus narrowed to top (Figs 12-15). Glans triangular, stylus long. Penis shaft length 2.7, glans -0.35 , stylus -0.15 .

Female. Body 6.6 long, 3.5 wide (Fig. 16). Differs from male in being larger, more roundish body and presence of denticles on eye mound. Chelicera: I segment 1.6, II - 1.8 (Figs. 17-18). Length of palpal segments: femur 1.3, patella 0.6, tibia 0.8, tarsus 1.7 (Figs. 19-20).

Lengths of legs: I $3.0+1.3+2.5+3.5+4.6=14.9$, II $6.5+2.0+6.0+5.6+10.2=30.3$, III $3.5+1.4+2.7+4.0+5.0=16.6$, IV 5.2+1.5+4.2+6.5+7.8 $=25.2$.

Diagnosis. Within the genus Homolophus, the present new species belongs to the short legged group of species shown in Figs 21-35, i.e. Homolophus przewalskii (Staręga, 1978) (Khakassia, Russia; Kazakhstan), H. gobiensis Tsurusaki, Tchemeris et Logunov, 2000 (Mongolia), H. vladimirae (Šilhavý, 1967) (Kazakhastan). H. nakhichevanicus sp. n. has similar short legs but differs from all of them by its penis structure and other details.

The most similar to the new species is Homolophus przewalskii (Figs 26-30), but differs from it by the followings characters: smaller size of the body (length 5.7 versus $9.90 \mathrm{~mm}$ ), shorter legs, eye mound very low, without denticles in males; anterior margin of cephalothorax with large denticles, forming a crown; chelicerae not very strong; pedipals shorter and segments thinner; glans of penis more triangular with two pair of setae. The new species differs 


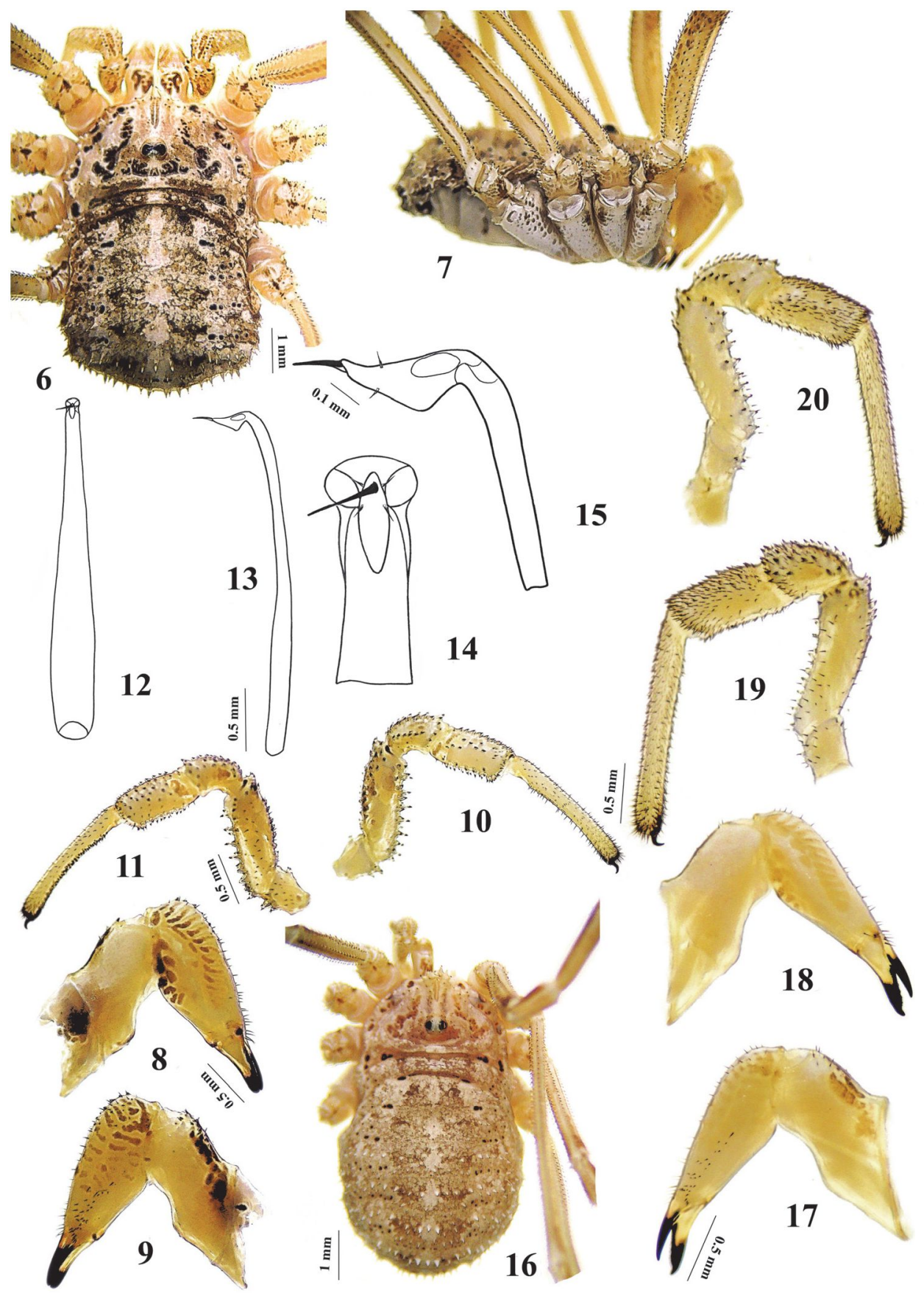

Figs 6-20. Homolophus nakhichevanicus sp. n.; 6-15-male, 16-20-female; 6-body, dorsal view; 7 - body, lateral view; 8 -right chelicera, retrolateral view; 9 - right chelicera, prolateral view; 10 -right pedipalpus, retrolateral view; 11 - right pedipalpus, prolateral view; 12 - ventral view of penis; 13 - lateral view of penis; 14 - glans, ventral view; 15 - glans of penis, lateral view; 16 - body, dorsal view; 17 - right chelicera, prolateral view; 18 - right chelicera, retrolateral view; 19 - right pedipalpus, prolateral view; 20 -right pedipalpus, retrolateral view. Scale bars: $3,4,13-$ $1 \mathrm{~mm} ; 5-10,14-17-0.5 \mathrm{~mm} ; 11-12-0.1 \mathrm{~mm}$. 


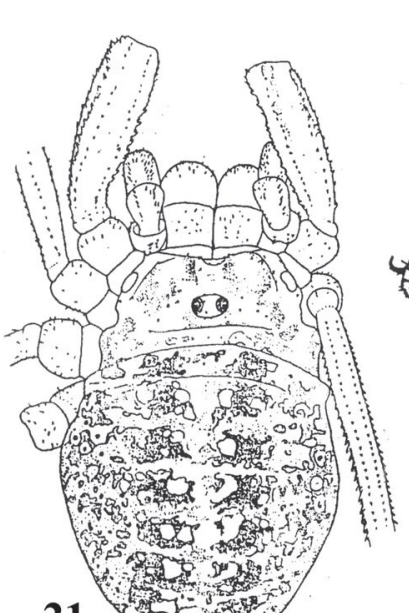

21

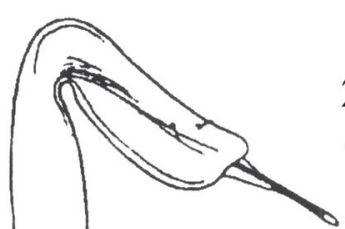

25
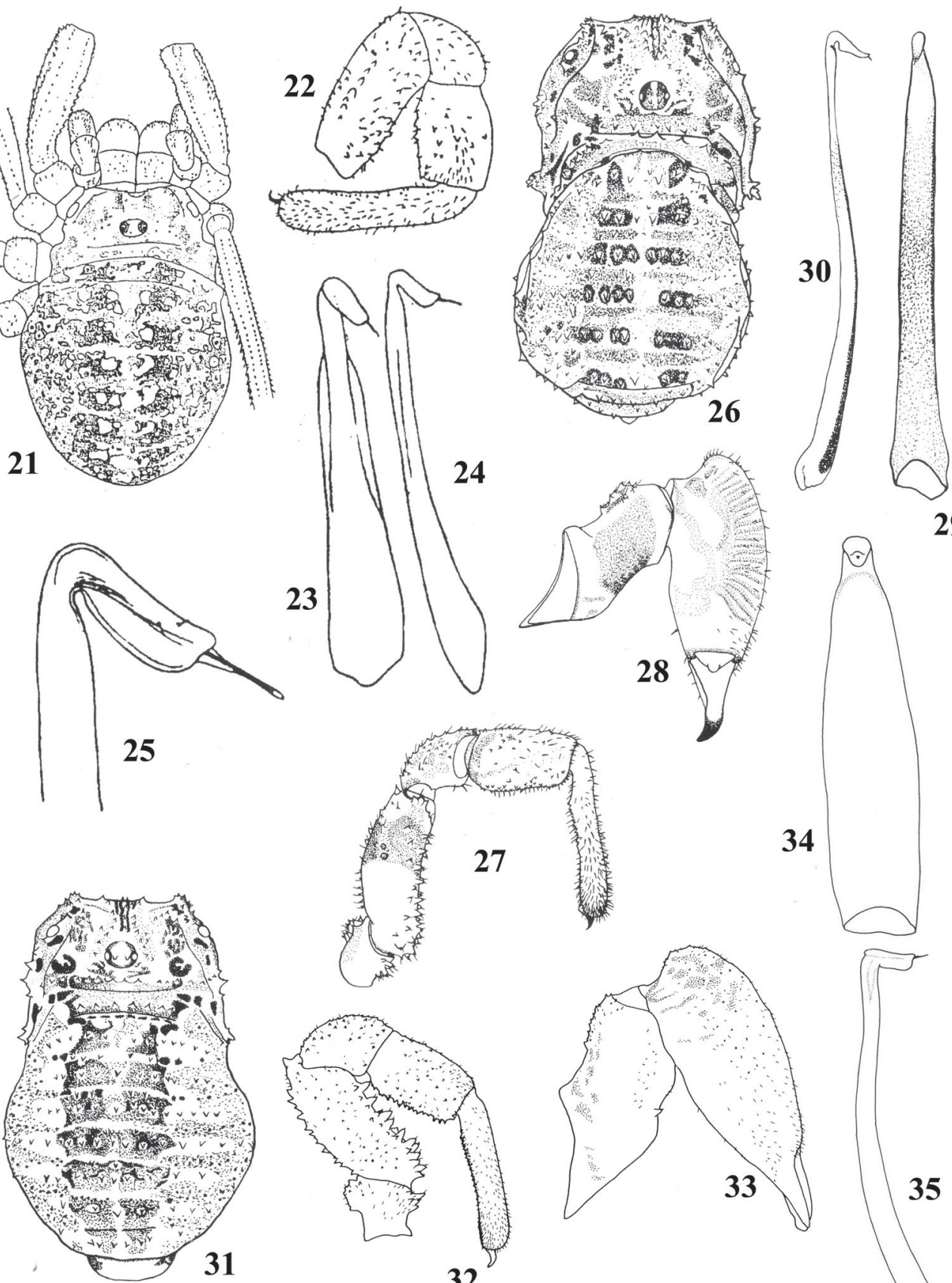

23
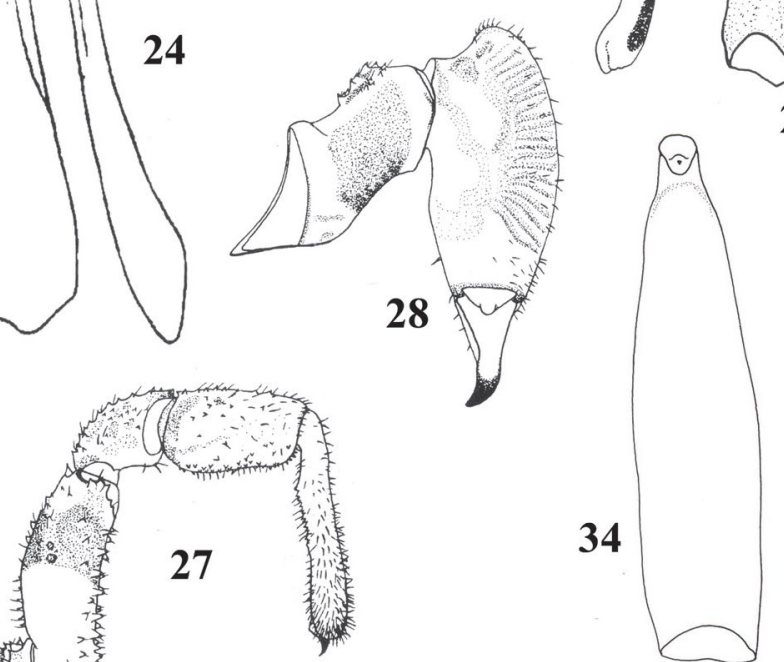

29
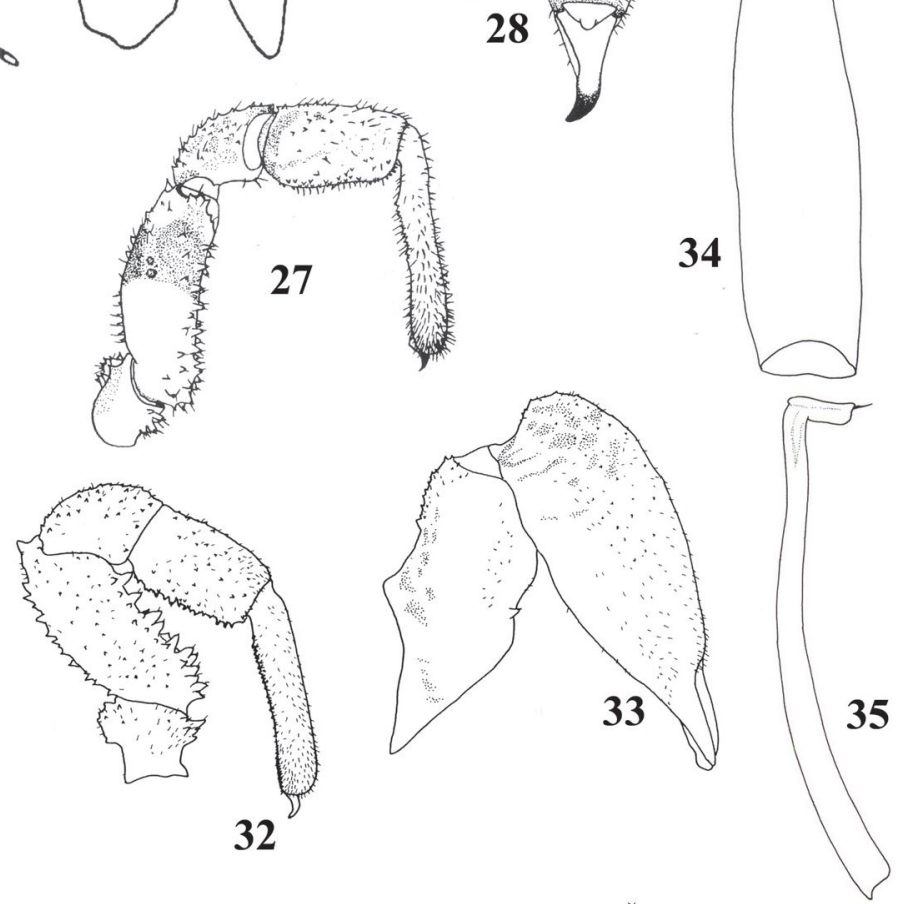

Figs 21-35. Different species of genus Homolophus. 21-25-Homolophus vladimirae (Šilhavý, 1967): 21 - body, dorsal view, 22-pedipalpus, lateral view, 23 - ventral view of penis, 24 - lateral view of penis, 25 - glans, lateral view; 26-30-Homolophus przewalskii (Staręga, 1978): 26 - body, dorsal view, 27 - pedipalpus, lateral view, 28 chelicerae, lateral view, 29 - ventral view of penis, 30 - lateral view of penis; 31-35-Homolophus gobiensis Tsurusaki, Tchemeris et Logunov, 2000: 31 - body, dorsal view, 32 - pedipalpus, lateral view, 33 - chelicerae, lateral view, 34 - ventral view of penis, 35 - lateral view of penis. 
from $H$. vladimirae (Figs 21-25) by less robust chelicerae, presence of large denticles on body surface and the structure of penis (H. vladimirae has appendages on the truncus of penis). $H$. nakhichevanicus sp. n. differs from $H$. gobiensis (Figs. 31-35) also by less robust chelicerae and pedipalps and also by other penis structure (in $H$. gobiensis, penis is with thick and short truncus). The least similar to the new species is $H$. turcicus that differs by having shorter legs, presence of more developed denticles on anterior margin of cephalothorax, and by morphology of the penis.

\section{ACKNOWLEDGEMENTS}

The author is extremely grateful to Drs. Kh. Aliyev (Baku, Azerbaijan), M. Maherramov and A. Gasymov (both Nakhichevan, Azerbaijan) and Yu. Marusik (Magadan, Russia) for collected material and help during our stay in Nakhichevan. Mr. James Cokendolpher (Lubbock, Texas, USA) is thanked for checking the English text.

\section{REFERENCES}

COKENDOLPHER J. C. 1987. On the identity of the genus Homolophus: A senior synonym of Euphalangium (Opiliones: Phalangiidae). Acta Arachnologica 35: 89-96.

KuRT K., Demir H., SEyYAR O. \& TOPCU A. 2008. Some harvestmen records (Arachnida: Opiliones) from Nigde Province of Turkey. Serket 11:2-6.

MORN S. M. 1937. Kavkaz'ki Opiliones - kosari. Trudi Odes'kogo Deržavnogo Universitetu, Biologia 2: $209-222$.

RoEwer C. F. 1959. Die Araneae, Solifuga und Opiliones der Sammlungen des Herrn Dr. K. Lindberg aus Griechenland, Creta, Anatolien, Iran und Indien. Göteborgs Kungliga Vetenskaps- och Vitterhets-Samhälles handlingar, Göteborg, Ser. B, Matematiska och naturvetenskapliga skrifter, 8 (4): 1-47.

ŠLLHAVÝ V. 1967. Beitrag zur Kenntnis der Weberknecht-fauna des Sowjetischen Zentral-Asien (Arach., Opilionidea). Československá Společnost Entomologická, Praha, 64 (6): 472-478.

ŠLHAVÝ V. 1972. Asiatische Arten der Gattung Euphalangium Roewer (Arachnida: Opiliones: Phalangiidae). Senckenbergiana Biologica, Frankfurt, 53 (1/2): 101-108.

SNEGOVAYA N. Y.\& STAREGa W. 2008. A new Homolophus species (Opiliones: Phalangiidae) from Lenkoran zone in Azerbaijan. Acta Arachnologica 57 (1): 15-17.

SNEGOVAYA N. Y.\& STAREGA W. 2011. Harvestmen (Arachnida, Opiliones) from Talysh, with description of a new genus and other taxonomical changes. Fragmenta Faunistica 54: 47-58.

STAREGA W. 2003. On the identity and synonymies of some Asiatic Opilioninae (Opiliones: Phalangiidae). Acta Arachnologica 52 (2): 91-102.

TCHEMERIS A. N. 2000. Contribution to the knowledge of the harvestman fauna in the Russian Far East and Eastern Siberia (Arachnida: Opiliones). Arthropoda selecta, Moskva, 9 (1): 31-49.

TCHEMERIS A. N., LOGUNOV D. V. \& TSURUSAKI N. 1998. A contribution to the knowledge of the harvestman fauna of Siberia (Arachnida: Opiliones). Arthropoda Selecta 7: 189-199.

TSURUSAKI N., TCHEMERIS A. N. \& LOGUNOV D. V. 2000. Two new species of Opiliones from Southern Siberia and Mongolia, with an establishment of a new genus and redefinition of the genus Homolophus (Arachnida: Opiliones: Phalangiidae). Acta Arachnologica 49 (1): $73-86$.

\section{STRESZCZENIE}

[Nowy gatunek z rodzaju Homolophus (Arachnida: Opiliones: Phalangiidae) z Nakhichevan Autonomous Republic (Azerbaijan)]

Praca zawiera opis nowego gatunku kosarza Homolophus nakhichevanicus sp. n. z rodziny Phalangiidae wraz $\mathrm{z}$ fotografiami i rysunkami. Okazy tego gatunku znaleziono w górach na terytorium Autonomicznej Republiki Nakhichevan (Azerbejdżan). Jest to ósmy gatunek kosarza wykazany z tego obszaru. 